Stepaniuk K., An importance of trust in virtual systems of hospitality exchange according to Polish users of couchsurfing.org, „Economics and Law”, Polszakiewicz B., Boehlke J. (ed.), Vol. 13, No. 1/2014, pp. 109-120. DOI: http://dx.doi.org/10.12775/EiP.2014.009.

\title{
AN IMPORTANCE OF TRUST IN VIRTUAL SYSTEMS OF HOSPITALITY EXCHANGE ACCORDING TO POLISH USERS OF COUCHSURFING.ORG
}

\section{SUMMARY}

The article presents the analysis of opinions of active tourists who are the members of a hospitality exchange network, as well as people who do not belong to it, on the subject of the importance of trust and its influence on the development of modern alternative tourism based on the idea of the couchsurfing in Poland.

The following has been analyzed: 1. the level of trust of the couchsurfing.org website users (CU) in relation to other members of the community, 2. the causes of not using the possibilities of the couchsurfing.org website by active tourists who are not its users (NCU), 3. the relation between recommendation from people who are the members of the couchsurfing.org community and the possibility of activating people not interested in the website within the couchsurfing. The research has been conducted by a survey method.

Analyzing the obtained data it has been stated that a typical CU in Poland $(=110)$ is a working man at the age of 24-29 with a higher education, inhabiting mainly big cities. It is a single person declaring a good material situation. He also knows one foreign language in a communicative level. CU indicate that difficulties in planning and accomplishing a longer trip as well as the lack of the sense of independence during a journey are the main drawbacks of trips organized via a hospitality exchange

"Krzysztof Stepaniuk, Bialystok University of Technology, Faculty of Management, Department of Tourism and Recreation, ul. o. S. Tarasiuka 2, 16-001 Kleosin, phone: +48 8574698 52, e-mail: k.stepaniuk@pb.edu.pl. 
network. Whereas in the case of NCU she is a working woman $(=45)$ at the age of 3039 having a higher education and being in an informal relationship. The respondents declare a good material situation and the knowledge of one foreign language.

Not using the possibilities of the website by NCU is mainly connected with the lack of trust towards unknown people. At the same time, NCU are not interested in being active in the website, despite the recommendation given them by a familiar person who is a member of the couchsurfing.org community.

Keywords: trust, hospitality exchange systems, couchsurfing JEL Classification: Z, Z1

\section{INTRODUCTION}

The article presents an analysis of the opinions of active tourists who are the members of hospitality exchange networks, as well as those who do not belong to it, on the subject of the importance of trust and its influence on the development of contemporary alternative tourism based on the idea of couchsufring in Poland.

\section{THEORETICAL BASIS}

Web 2.0 revolution, via Social Media - SM among other things, destroys geographical and social barriers. Owing to this property, there is a possibility to create virtual communities ${ }^{1}$ which are directed to varied recipients while others attract people basing on common interests, race, sexuality, religion or national identity ${ }^{2}$. Forming this type of community around the issues of broadly defined alternative tourism is therefore obvious and justified.

A basic distinguishing mark of alternative tourism is its distinctness from so called mass tourism ${ }^{3}$ which is regarded as socially burdensome and with a negative influence on the condition of natural environment ${ }^{4}$ in an essential way. Therefore, alternative tourism is defined as a touristic activity involving

${ }^{1}$ W. Lange-Faria, S. Elliot, Understanding the role of social media in destination marketing, „Tourismos. An International Multidisciplinary Journal of Tourism”, Vol. 7, No. 1/2012, p. 193-211.

2 S. Grabner-Kräuter, Web 2.0 Social Networks: The Role of Trust, „Journal of Business Ethics”, Vol. 90/2009, p. 507.

3 T. Łobożewicz, G. Bieńczyk, Podstawy turystyki, Wyższa Szkoła Ekonomiczna, Warszawa 2001, p. 123.

${ }^{4}$ C. Kasper, Die tourismuslehre im Grundriss, Verlag Paul Haupt, Stuttgart 1991 [from:] T. Łobożewicz, G. Bieńczyk, op. cit., p. 120. 
travelling and contacting people who belong to other social, national or ethical groups in order to get to know their distinct lifestyles, cultural heritage, etc. without having a negative influence on the destination area ${ }^{5}$.

From the perspective of alternative tourism development and in context of Internet social media, a problem of communication between people of similar touristic interests as well as a problem of factors that influence the formation of relations between them become essential.

Hospitality exchange networks facilitate travelling to distant places, familiarization with local culture, satisfaction of varied emotional needs without using a traditional lodging place and its touristic infrastructure. The idea of this kind of phenomenon is connected with a theory of so called gift culture ${ }^{6}$, according to which people owning a certain possession grant it to others without requiring any material or non material profits for themselves. In the case of a hospitality exchange network, providing a lodging place, guiding services or own companionship to an unknown person, who may come from a foreign country or even a distant continent, can be a gift. A touristic activity and a membership in the community of couchsurfers, i.e. people using the website couchsurfing.org are the only common elements that join hosts with their guests.

The website, established in 2003, is at present the most popular hospitality exchange network and it associates five and a half million users coming from 207 countries. The most of the users of the couchsurfers community come from the United States, France, Canada, Great Britain Spain, Italy, Brazil, Australia and China?.

The interactions between the users of social networks develop into secondary social relationships, i.e. casual and lacking a strong emotional dependence context among the members of the groups who share common and restricted to some extent interests, opinions or activities ${ }^{8}$. Therefore, similarly as in the real world, the users of social networks form groups in which they not only exchange information but also, for instance, goods. One of the essential elements which can determine the strength and quality of the established contacts is trust between people becoming related via the Internet ${ }^{9}$.

${ }^{5}$ V.L. Smith, W.R. Eadington, Tourism Alternatives: Potentials and Problems in the Development of Tourism, Univeristy of Pennsylvania Press, Philadelphia 1992, p. 18.

${ }^{6}$ D.J. Cheal, The Gift Economy, Routledge, New York 1988, pp. 1-19.

7 Couchsurfing.org, http://www.couchsurfing.org/statistics (31.07.2013).

${ }^{8}$ A. Podgórecki, M.W. Łoś, Multi-Dimensional Sociology, Routledge \& Kegan Paul, London 1979.

${ }^{9}$ B. Krawczyk-Bryłka, Budowanie zaufania w relacjach internetowych, [in:] B. Szmigielska (red.), Psychologiczne konteksty Internetu, Wydawnictwo WAM , Kraków 2009, p. 119. 
Trust is the key element influencing a decision whether to enter into an interaction between the users of social networks, and building it takes place through the possibility of acquiring information about previous activities of other users, gathered in a particular community ${ }^{10}$.

Bialski and Batorski claim that the level of trust is connected to the nature of relation among users. People who know each other owing to meetings in reality among other things show higher level of mutual trust than people who know and contact each other only online, however, in this case, the level of trust increases with the duration of this kind of relation ${ }^{11}$. It is possible to state that the duration of the relation is of a key importance in this case. It is confirmed by Sztompka among other things, suggesting that the evanescence of contacts is not conductive to proper and individual assessment of potential partner's credibility in online contacts ${ }^{12}$. At the same time, the author distinguishes five basic determinants of trust in the Internet ${ }^{13}$ :

- a calculation of trust is connected to the subjective assessment of selfpresentation of a person within a profile in a social network;

- immanent credibility, connected with e.g. recommendations from other users;

- impulse and culture of trust;

- forced credibility, connected e.g. with the possibility of exacting additional attributes increasing the level of trust from an interested user.

Niedźwiedziński suggest that anxieties of e-consumers, (the couchsurfers), result from traditional „paper mentality” and impossibilities of switching to „electronic mentality” ${ }^{14}$.

Trust makes uncertainty more comprehensible or generates positive fiction, and thus partly eliminates the sense of uncertainty that acompanies contacts with an unknown person ${ }^{15}$. Couchsurfing.org uses a reputation system to collect and disseminate information among members ${ }^{16}$. As couchsurfers trav-

${ }^{10}$ P. Resnick, K. Kuwabara, R. Zeckhauser, E. Friedman, Reputation systems, „Communications of the ACM", Vol. 43/2000, pp. 45-48.

${ }^{11}$ P. Bialski, D. Batorski, Trust Networks: Analyzing the Structure and Function of Trust, International Network of Social Network Analysis SUNBELT Conference, Corfu, Greece, 2007.

12 P. Sztompka, Zaufanie. Fundament spoteczeństwa, Wydawnictwo Znak, Kraków 2007, p. 383.

13 Ibidem, p. 134-135.

${ }^{14}$ M. Niedźwiedziński, Globalny handel elektroniczny, Wydawnictwo Naukowe PWN, Warszawa 2004, s. 26.

15 G. Möllering, Trust: Reason, Routine Reflexivity, Elsevier Ltd., Oxford 2006, p. 105-111.

16 D. Lauterbach, H. Truong, T. Shah, L. Adamic, Surfing a web of trust:reputation and reciprocity on Couchsurfing.com, 2009 International Conference on Computational Science and Engineering (CSE)/2009, p. 346-353. 
el, host, or participate in local activities, they build up a reputation through the references other couchsurfers leave for them - and they leave for others ${ }^{17}$. Consequently, the calculation of trust and credibility, as basic contents visible in the profile of a social network user, seem to be essential in establishing contact and making a decision about providing lodging or using it. However, the lack of trust can constitute a barrier for alternative tourism based on the systems of hospitality exchange.

\section{RESEARCH HYPOTHESIS}

On the basis of the review of literature presented above, a working hypothesis has been suggested, according to which the lack of trust is the main barrier of the development of alternative tourism based on the systems of hospitality exchange, which is particularly connected with:

- a limited level of trust of the network users in relation to other members of the couchsurfing.org community, which is mainly connected with the fear of the possibility of potential problems in planning and implementation of a longer trip that may appear (e.g. refusal of providing lodging in the last moment) - H1;

- not using the possibilities of the couchsurfing.org website by active tourists who, being aware of its existence, are not the members of the couchusrfers community, which is mainly connected with the lack of trust towards unknown people and their self-presentation in their profiles on the website - H2;

- the lack of positive correlation between the recommendation of the members of the couchsurfing.org community who are known to active tourists that are not the users of the website connected with the possibility of activating them within the couchsurfing - H3.

\section{MATERIAL AND METHODS}

The users of the couchsurfing.org website as well as active tourists, who have heard of its existence in any way but are not its users, have been taken into the research. The nature of such approach was to compare the opinions of both of the groups on the subject of the main barriers of the devel-

17 J. Germann Molz, Social networking technologies and the moral economy of alternative tourism: The case of couchsurfing.org, „Annals of Tourism Research”, Vol. 43/2013, p. 210-230. 
opment of hospitality exchange systems in Poland, based on the assumption that people who are not the members of the couchsurfingu.org community will have more doubts and concerns than those who are the users and travel in this way.

The questionnaire of the survey consisted of thirty five questions, including three open ones. It was made in an electronic form with the help of a Google Docs tool and sent to five hundred selected people (250 website users and 250 users of touristic forums) in such a form. The feedback was received from 210 respondents, from which the results of 155 people were used for this paper - the questionnaires of people who have never heard of the couchsurfing.org website were discarded. It needs to be noted that the received feedback surveys were in many cases incomplete, thus the received results have been presented only in the form of descriptive statistics which are not of representative nature.

The research works were accomplished in June 2013.

\section{RESULTS}

\subsection{RESPONDENT'S PROFILE}

According to the character of the work, the respondents have been divided into two groups. The first group consisted of people who own their profiles in the couchsurfing.org website, whereas the other one included people that have heard of the website, however do not use its possibilities (table 1.).

Table 1. Respondent's profile (CU - couchsurfing.org users; NCU - non couchsurfing.org users)

\begin{tabular}{|c|c|c|c|}
\hline \multirow{2}{*}{ PARAMETER } & \multirow{2}{*}{ PARAMETER'S ATTRIBUTES } & CU & NCU \\
\hline & & $(=110)$ AMOUNT $(\%)$ & $(=45)$ AMOUNT $(\%)$ \\
\hline \multirow{2}{*}{ Sex } & women & $47(43 \%)$ & $23(56 \%)$ \\
\hline & men & $63(57 \%)$ & $18(44 \%)$ \\
\hline \multirow{5}{*}{ Place of living } & village & $10(9 \%)$ & $3(7 \%)$ \\
\hline & town $<10000$ inhabitants & $4(4 \%)$ & $1(2 \%)$ \\
\hline & $\begin{array}{l}\text { city from } 10 \text { to } 100 \text { tho- } \\
\text { usand inhabitants }\end{array}$ & $30(27 \%)$ & $6(15 \%)$ \\
\hline & $\begin{array}{l}\text { city from } 100 \text { to } 500 \text { tho- } \\
\text { usand inhabitants }\end{array}$ & $27(25 \%)$ & $5(12 \%)$ \\
\hline & $\begin{array}{l}\text { city above } 500 \text { thousand } \\
\text { inhabitants }\end{array}$ & $39(35 \%)$ & $26(64 \%)$ \\
\hline
\end{tabular}




\begin{tabular}{|c|c|c|c|}
\hline \multirow{2}{*}{ PARAMETER } & \multirow{2}{*}{ PARAMETER'S ATTRIBUTES } & CU & NCU \\
\hline & & $(=110)$ AMOUNT $(\%)$ & $(=45)$ AMOUNT $(\%)$ \\
\hline \multirow{5}{*}{ Age } & $18-24$ years & $54(49 \%)$ & $9(22 \%)$ \\
\hline & $25-29$ years & $37(34 \%)$ & $12(29 \%)$ \\
\hline & 30-39 years & $15(14 \%)$ & $13(32 \%)$ \\
\hline & $40-49$ years & $2(2 \%)$ & $5(12 \%)$ \\
\hline & $50-59$ years & $2(2 \%)$ & $2(5 \%)$ \\
\hline \multirow{2}{*}{ Education } & secondary & $26(24 \%)$ & $7(17 \%)$ \\
\hline & higher & $84(76 \%)$ & $34(83 \%)$ \\
\hline \multirow{3}{*}{ Professional status } & worker & $58(53 \%)$ & $28(68 \%)$ \\
\hline & pupil/student & $49(45 \%)$ & $10(24 \%)$ \\
\hline & $\begin{array}{l}\text { unemployed person or non } \\
\text { pupil/student }\end{array}$ & $3(3 \%)$ & $3(7 \%)$ \\
\hline \multirow{3}{*}{ Martial status } & single & $50(45 \%)$ & $13(32 \%)$ \\
\hline & in informal relationship & $46(42 \%)$ & $16(39 \%)$ \\
\hline & married & $14(13 \%)$ & $2(29 \%)$ \\
\hline \multirow{4}{*}{$\begin{array}{c}\text { Material situation } \\
\text { (subjective assessment) }\end{array}$} & very good & $9(8 \%)$ & $8(20 \%)$ \\
\hline & good & $54(49 \%)$ & $24(59 \%)$ \\
\hline & average & $44(40 \%)$ & $9(22 \%)$ \\
\hline & rather bad & $3(3 \%)$ & - \\
\hline \multirow{5}{*}{$\begin{array}{l}\text { Declared knowledge of fo- } \\
\text { reign languages in commu- } \\
\text { nicative level }\end{array}$} & 0 (only mother tongue) & $2(2 \%)$ & $1(2 \%)$ \\
\hline & 1 & $57(52 \%)$ & $24(59 \%)$ \\
\hline & 2 & $37(34 \%)$ & $14(34 \%)$ \\
\hline & 3 & $9(8 \%)$ & $1(2 \%)$ \\
\hline & 4 and more & $5(5 \%)$ & $1(2 \%)$ \\
\hline \multirow{4}{*}{$\begin{array}{l}\text { Touristic activity } \\
\text { (declared number of touri- } \\
\text { stic trips a year) }\end{array}$} & more than 4 times a year & $56(51 \%)$ & $24(59 \%)$ \\
\hline & 3-4 times a year & $33(30 \%)$ & $9(22 \%)$ \\
\hline & 1-2 times a year & $19(17 \%)$ & $8(20 \%)$ \\
\hline & once a several of years & $2(2 \%)$ & - \\
\hline
\end{tabular}

Source: Own study based on the obtained results.

On the basis of the data presented in the Table 1 , it needs to be stated that a typical user of the couchsurfing.org website, taking part in the objective research, is a working man at the age of 24-29, living in a big city (of more than 500 thousand inhabitants) and having higher education. It is a single person of a good material situation declared. They also know one foreign language on a communicative level.

However, in the case of people who do not own a profile in the couchsurfing website but aware of its existence and offered possibilities, a typical representative of the surveyed is a working woman at the age of 30-39, with higher education, in an informal relationship and of a good material situation declared as well as with the knowledge of one foreign language. 
In the case of both groups, the similarities concern the place of living (big cities), declared material situation, professional status, education and language competence as well as touristic activity.

\subsection{TRUST IN THE VIRTUAL HOSPITALITY EXCHANGE SYSTEMS IN POLAND ON THE EXAMPLE OF COUCHSURFING.ORG}

The analysis of the respondents' touristic activity indicates that they travel very frequently. The respondents $(=110)$ who are the couschsurfing.org users (CU) declared that they most often travel with their partners (35\%), friends (33\%), individually $(25 \%)$ or with their families (7\%). Whereas, non couschsurfing.org users (NCU, $=45)$, similarly as in the former case, most often travel with their partners (49\%) or individually (25\%). Travelling with families $(12 \%)$, friends $(12 \%)$ or people met on the Internet forums (2\%) (e.g. www. fly4free.com.p1/forum) were the least popular.

The majority of CU declares using lodging as guests (87\%), while 52\% provide lodging to others. Not many over $37 \%$ of the active couchsurfers guide their guests round their places of living and surroundings, whereas 15\% of respondents indicate to participation in the meetings of the community members. Less than $4 \%$ of the people who have their profiles on the website do not uses it in any way.

The couchsurfing.org website users have declared a relatively high level of safety during their trips. As many as $83 \%$ of them do not recall any unpleasant or dangerous incidents during their contacts with other users while travelling. $17 \%$ of the respondents were of contrary opinions.

Similar results have been achieved having surveyed CU about the level of protection used within the website, i.e. references, verification of users as well as the system of guarantees given by other users (co called vouching), where $79 \%$ of the respondents stated that they are sufficient, however $21 \%$ were of contrary opinions.

In a controlling question, $\mathrm{CU}$ respondents were asked whether using the lodgings found with the help of the website was risky. One fifth of the respondents definitely did not agree with this statement, a little more than half of them (51\%) rather did not agree. $10 \%$ of the respondents were of opposite opinions ( $9 \%$ - rather do not agree and 1\% - definitely do not agree). $20 \%$ of the surveyed people were of no opinion.

The surveyed users also indicated potential problems and disadvantages of travelling with the use of the possibilities of the analyzed website that they had noticed. The details have been presented on figure 1 . 


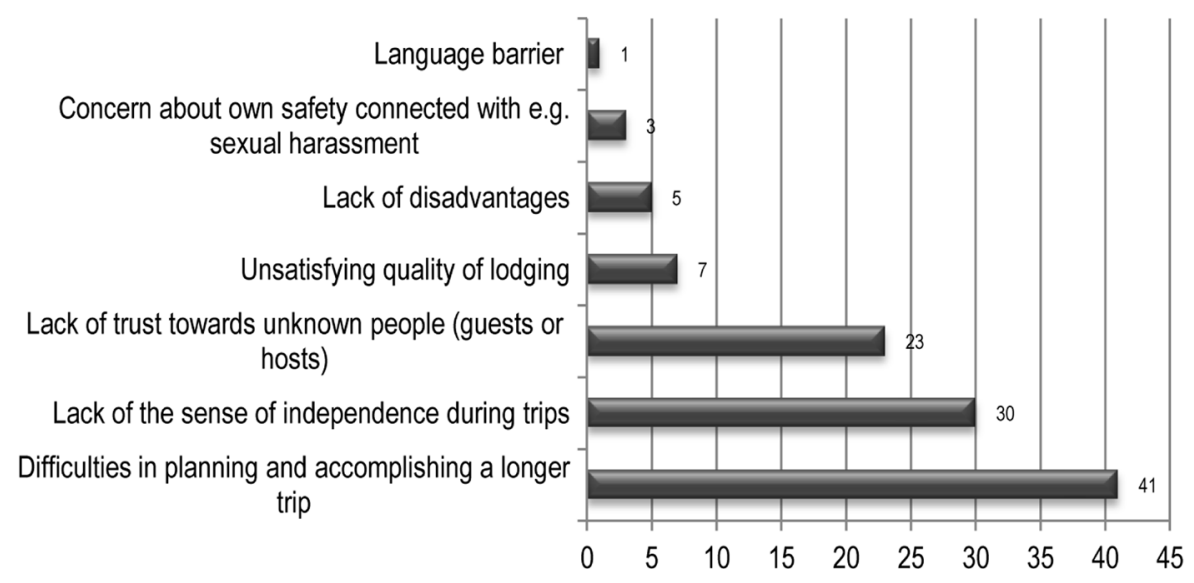

Figure 1. Main disadvantages of touristic trips with the use of couchsurfing.org website according to the respondents $(=110)$

Source: Own preparation based on obtained results.

The respondents indicated to having difficulties in planning and accomplishing a longer trip as the main disadvantage of travelling based on the couchsurfing (37\%). $27 \%$ of the respondents pointed to the lack of the sense of independence, while the lack of trust is a problem to $21 \%$ of the surveyed. Low comfort of lodging (6\%), concern about own safety, connected with e.g. sexual harassment $(3 \%)$ and a language barrier $(>1 \%)$ are the most rarely indicated disadvantages by the respondents. Less that $4 \%$ of the respondents do not notice disadvantages in this kind of trips.

Active tourists but non members of the couchsurfing community (NCU) were asked about the main reasons of their lack of interest in the website. Among forty five respondents only twenty seven people answered, which constitutes $60 \%$ of the total number of the surveyed from this group. (figure 2).

The lack of trust to unknown people is the main reason of not showing interest in possibilities of the couchsurfing.org website for the majority of people who are not its users (44\%). The other reasons are the lack of the sense of independence during a trip (26\%) as well as unsatisfactory quality of the lodging (15\%). Difficulties in planning and accomplishing a longer trip and a language barrier are the most rarely indicated reasons of the lack of interest.

The majority of the respondents from this group - 62\% - would not be interested in registering and using the possibilities of the website despite the awareness that working and the efficiency of the tools which influence the safety of its users, i.e. a reference system, vouching as well as the verification of the identify of a profile's owner had been improved. Answering the 
next question $(=24)$, the respondents stated in majority $(71 \%)$ that nothing could influence the increase in their interest in the website. The rest of them could be interested if the website and its possibilities were recommended by a friendly member of the couchsurfers community (17\%) or the efficiency of the tools that increase the safety of the website's users was improved (12\%).

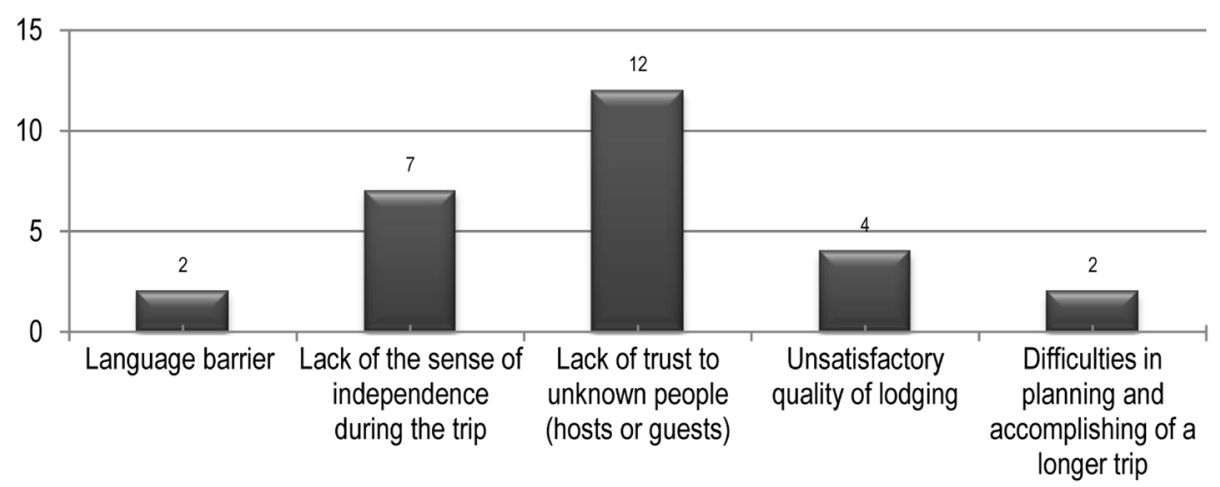

Figure 2. The main reasons of the lack of interest in the couchsurfing.org website among active tourists according to the respondents $(n=27)$

Source: Own preparation based on obtained results.

\section{DISCUSSION}

According to the rational choice theory, Sztompka ${ }^{18}$ suggests that trustworthy people and those who trust others aim at maximizing their own benefits assessing available data. Therefore, basing on the information about other website's users placed in their profiles, the members of the couchsurfing community calculate trust and assess immanent credibility on the basis of culture and trust impulse. Then, having contacted each other, they can analyze the remaining determinants of trust (e.g. forced credibility) and consequently, in this way, they can maximize their own benefits in the form of obtaining the best place of lodging and/or company, not running the risk of having any problems.

At the same time, the author suggests that the level of trust among the members of the Internet community is bigger the more common interests and values there are among the people that constitute $i t^{19}$. Thus, the majority

${ }_{18}$ P. Sztompka, op. cit., p. 134-135.

19 Ibidem, p. 386. 
of surveyed CU did not indicate the lack of trust to unknown people as the main defect because they should be people of similar interests and preferences, in this case - touristic. However, NCU indicate to the lack of trust to unknown people as the main drawback influencing their lack of interest in the couchsurfing. CU, in strong majority, also declared high level of safety of trips based on the couchsurfing.

$\mathrm{CU}$ indicate to problems connected to planning a longer trip as a main drawback of tourism based on the couchsurfing which can be partly connected with limited trust towards the members of the couchsurfing community. This restriction of trust can be related to many aspects, among other things to a concern connected to a possibility of refusal of providing lodging in the very last moment, e.g. during an ongoing trip. Defining the importance of this phenomenon for the development of alternative tourism based on the couchsurfing in Poland will require further research.

\section{CONCLUSIONS}

The results of the conducted research allow to state that:

The surveyed users of the couchsurfing.org website indicate that difficulties in planning and accomplishing a longer trip as well as the lack of the sense of independence during a trip are the main drawbacks of trips organized via a hospitality exchange network. Restricted level of trust towards other members of couchsurfing.org community is indicated as the third element in order which can be a barrier for trips organized within the couchsurfers community. Bearing that in mind, it should be stated that the H1 hypothesis has not been confirmed.

The surveyed active tourists who are not couchsurfers, despite their being aware of a hospitality exchange network, do not use its possibilities and do not decide to become members of the community. It is mainly connected with the lack of trust towards unknown people. It can be stated that the $\mathrm{H} 2$ hypothesis has been confirmed.

The non couchsurfing respondents, who participated in the research, have at the same time confirmed the lack of positive correlation between website's recommendation given to them by a familiar person - a member of couchsurfing.org community and a possibility of activating them within the couchsurfing. The $\mathrm{H} 3$ hypothesis has also been positively verified .

At the same time, the attention should be drawn to the fact that a vast group of the respondents belonging to non couchsurfers (around 40\%) has not defined its attitude towards the former two points. The explanation of the causes of this phenomenon requires further, detailed research. 


\section{BIBLIOGRAPHY}

Bialski P. Batorski D., Trust Networks: Analyzing the Structure and Function of Trust, International Network of Social Network Analysis SUNBELT Conference, Corfu, Greece, 2007.

Cheal D.J., The Gift Economy, Routledge, New York, 1988.

Couchsurfing.org, http://www.couchsurfing.org/statistics (31.07.2013).

Germann Molz J., Social networking technologies and the moral economy of alternative tourism: The case of couchsurfing.org, „Annals of Tourism Research”, Vol. 43/2013, http://dx.doi.org/10.1016/j.annals.2013.08.001.

Grabner-Kräuter S., Web 2.0 Social Networks: The Role of Trust, „Journal of Business Ethics”, Vol. 90/2009, http://dx.doi.org/10.1007/S10551-010-0603-1.

Kasper C., Die tourismuslehre im Grundriss, Verlag Paul Haupt, Stuttgart 1991 [from:] T. Łobożewicz, G. Bieńczyk (ed.), Podstawy turystyki, Wyższa Szkoła Ekonomiczna, Warszawa, 2001.

Krawczyk-Bryłka B., Budowanie zaufania w relacjach internetowych, [in:] B. Szmigielska (ed.), Psychologiczne konteksty Internetu, Wydawnictwo WAM, Kraków 2009.

Lange-Faria W., Elliot S., Understanding the role of social media in destination marketing, „Tourismos. An International Multidisciplinary Journal of Tourism”, Vol. 7, No. $1 / 2012$.

Lauterbach D., Truong H., Shah T., Adamic L., Surfing a web of trust:reputation and reciprocity on Couchsurfing.com, 2009 International Conference on Computational Science and Engineering (CSE), 2009.

Łobożewicz T., Bieńczyk G. (ed.), Podstawy turystyki, Wyższa Szkoła Ekonomiczna, Warszawa, 2001.

Möllering G., Trust: Reason, Routine Reflexivity, Elsevier Ltd., Oxford 2006.

Niedźwiedziński M., Globalny handel elektroniczny, Wydawnictwo Naukowe PWN, Warszawa 2004.

Podgórecki A., Łoś M.W., Multi-Dimensional Sociology, Routledge \& Kegan Paul, London 1979.

Resnick P., Kuwabara K., Zeckhauser R., Friedman E., Reputation systems, „Communications of the ACM", Vol. 43/2000.

Smith V.L., Eadington W.R., Tourism Alternatives: Potentials and Problems in the Development of Tourism, Univeristy of Pennsylvania Press, Philadelphia 1992.

Sztompka P., Zaufanie. Fundament spoteczeństwa, Wydawnictwo Znak, Kraków 2007. 